\title{
Role of Teacher in Enhancing Quality Education of Secondary Level Public School of Nepal
}

\author{
Tanka Prasad Dahal \\ PhD Scholar of Mewar University, Rajasthan, India, \\ Dr. Pooja Gupta \\ Associate Professor, Principal, HoD (Department of education), Dean, Mewar \\ University, Chitorgarh, Rajastan, india \\ \& \\ Prof. Dr. Chandreshwor Mishra \\ Tribhuvan University, Kathmandu, Nepal
}

\section{Corresponding Author}

Tanka Prasad Dahal

Email: dahaltp1@gmail.com

\begin{abstract}
Teachers are the guardians of civilization; they are the role model for the students. So, the role of teacher is very important to enhance the quality education and increase the performance of students. The main objective of this study was to identify the role of teacher in enhancing the quality education. The study was conducted in Kathmandu, Dhanusa, Dolakha and Ramechhap district among the 388 stakeholders of education. Mixed method was used to collect the data. The result revels that there was significant different in the current level and expected level in role of teachers. The mean value of expected level was higher than the current level of role of teachers in enhancing the quality education so it can be concluded that there is need of improvement in the role of teachers. The concerned authority of schools should provide the opportunity to teachers to participate in the advance level of training program to enhance their teaching and learning capacity which ultimately can contribute in the quality education of school.
\end{abstract}

\section{Keywords}

Education, Enhancing, Nepal, Quality, Role, School, Teacher

\section{Introduction}

Education is light of knowledge which develop the impressive personality of people and build self-confidence to lead the society and nation. Education transfer the skill in professional life and those skillful persons are backbone of development. So, quality of education is the main concern for all stakeholders. Students should be skillful along with their academic degree. 
Education is the most powerful weapon we can use to change the world and for selfenlightenment. This is so because quality education equips one with capability to interpret things rightly and applying the gathered information in real life scenarios (Thangeda, Baratiseng, \& ThatoyamodimoMompati, 2016 ). In the "Rigveda" education has been understood as something which makes a man self-reliant and selfless. In the "Üpanisadas" the process of education is regarded as one which enables the individual to rise above the self and attain the liberation of the soul. Panini regarded education as training which one gets from nature(Adhikary, 2018 ).Quality education entails the following aspects; learning resources, technology, program enrolled, modules done, lecturing methodology, attachments, qualifications, co-curricular activities, performance awards, students and lecturers perspective in the institution operating management also their opinions and appraisal toward education (Darling-Hammond, 2013).It is said that quality is not destination, it is a continuous journey. Quality means doing the right things right. Doing things right - is efficiency and doing right things is effectiveness (Nagoba \& Mantri, 2015).

Teacher quality is recognized as a huge factor in enhanced understudy results, yet generally few investigations in creating nations can claim to give thorough observational confirmation to evaluate the relationship (Wayne \& Youngs, 2003). "What goes on in the classroom, and the impact of the teacher and teaching, has been identified in numerous studies as the crucial variable for improving learning outcomes. The way teachers teach is of critical concern in any reform designed to improve quality" (UNESCO, 2004).

Considering the importance of role of teachers, the main objective of this study is to identify the role of teacher in enhancing the quality education in secondary level public school of Nepal.

\section{Materials \& Method}

The study was based on the mixed method; collected the data by using the both quantitative and qualitative tools. The study was conducted in four districts: Dhanusa, Kathmandu, Dolakha and Ramechhap. The data was collected from 388 respondents of school stakeholders: Head Teacher, Teacher, School Management Committee, Students and Parents. The structured questionnaire survey was done to collect the quantitative data and interview checklist was used to collect the qualitative data. The statistical analysis was done for the quantitative data whereas the narrative analysis was done for the qualitative data.

\section{Result \& Discussion}

The study had discussed on the role of teachers to enhancing the quality of education in secondary level school. The role of teacher is vital in determining the quality of teaching and learning, performance of students. A good teacher can produce the good student so quality of teachers and their contribution is important to enhance the quality education. In this concern, the 
study asked the questions to different stakeholders of education to know the role of teachers in current level and expected role of teacher.

The data presented in the Table 1 shows the data of factor loading value, mean and paired sample t-test. The study has compared the response of current level and expected level. The data shows that the factor loading value of all 15 questions is higher than 0.5 (minimum 0.55 to maximum 0.87 in practice level and minimum 0.56 to maximum 0.96 in expected level) in both level. Similarly, the mean value of all 15 questions in current level was minimum 2.81 to maximum 3.77 for current level whereas the mean value of expected level was minimum 3.90 to maximum 4.57 for expected level. The result clearly indicates that the role of teacher need to be enhanced for the improvement of quality education in secondary level public school of Nepal. The mean value of expected level in each question was higher than the current level of practice. Current level of effort of teachers in moderately satisfactory level because the maximum mean value was only 3.77; slightly close to the 'High level of competency'.

Table 1: Role of Teachers

\begin{tabular}{|c|c|c|c|c|c|c|c|c|}
\hline \multirow[b]{2}{*}{ Role of Teachers } & \multicolumn{2}{|c|}{$\begin{array}{c}\text { Factor } \\
\text { Loading } \\
\text { value } \\
\end{array}$} & \multicolumn{3}{|c|}{ Mean } & \multicolumn{3}{|c|}{$\begin{array}{l}\text { Paired sample t- } \\
\text { test }\end{array}$} \\
\hline & 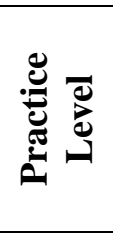 & 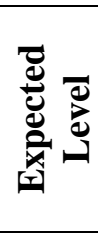 & $\underset{ٍ}{\vec{d}}$ & 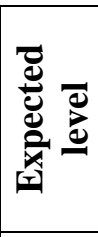 & 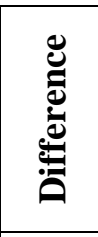 & 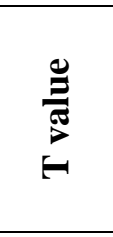 & $\ddot{a}$ & 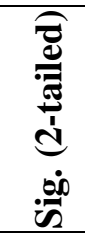 \\
\hline Teacher is very punctual in class ltime & 0.87 & 0.66 & 3.70 & 4.53 & $\begin{array}{ll}- \\
0.83\end{array}$ & - & 343 & .000 \\
\hline $\begin{array}{l}\text { Teacher always complete the assigned course in } \\
\text { time }\end{array}$ & 0.79 & 0.64 & 3.77 & 4.57 & - & -17.16 & 343 & .000 \\
\hline $\begin{array}{l}\text { Teacher adopts the practical method to teach the } \\
\text { students. }\end{array}$ & 0.72 & 0.70 & 3.57 & 4.43 & $\begin{array}{ll}- \\
0.86 \\
\end{array}$ & 16.62 & 344 & .000 \\
\hline $\begin{array}{l}\text { Teacher gives assignment to student and } \\
\text { regularly checks the given assignments. }\end{array}$ & 0.55 & 0.69 & 3.24 & 4.37 & $-\overline{1}$ & $-\overline{22.35}$ & 352 & .000 \\
\hline $\begin{array}{l}\text { Teacher uses new technologies (computer, } \\
\text { internet, power point presentation, online library } \\
\text { etc.) in their daily teaching practice. }\end{array}$ & 0.71 & 0.72 & 2.81 & 4.15 & $-\overline{1}$ & -21.7 & 353 & .000 \\
\hline $\begin{array}{l}\text { Teacher organizes extra curriculum for student } \\
\text { learning opportunities. }\end{array}$ & 0.78 & 0.76 & 3.07 & 4.16 & - & $-\overline{20.73}$ & 352 & .000 \\
\hline $\begin{array}{l}\text { Teacher regularly assess the student learning } \\
\text { progression. }\end{array}$ & 0.63 & 0.74 & 3.60 & 4.45 & $\begin{array}{ll}- \\
0.85 \\
\end{array}$ & $-\overline{1}-9.94$ & 351 & .000 \\
\hline Teacher deals with student heterogeneity. & 0.80 & 0.96 & 3.05 & 3.90 & - & - & 352 & .000 \\
\hline $\begin{array}{l}\text { Teacher encourages to develop the commitment } \\
\text { of student in their working and learning. }\end{array}$ & 0.56 & 0.67 & 3.55 & 4.44 & $-\overline{0}$ & $-\overline{2}$ & 353 & .000 \\
\hline
\end{tabular}




\begin{tabular}{|c|c|c|c|c|c|c|c|c|}
\hline $\begin{array}{l}\text { Teacher always works in teams for the } \\
\text { promotion of quality education. }\end{array}$ & 0.71 & 0.67 & 3.40 & 4.39 & - & 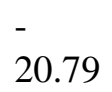 & 353 & .000 \\
\hline $\begin{array}{l}\text { Teacher participates in developing the school } \\
\text { curriculum. }\end{array}$ & 0.66 & 0.70 & 3.52 & 4.39 & $\overline{-} .87$ & $\begin{array}{l}- \\
19.94\end{array}$ & 352 & .000 \\
\hline $\begin{array}{l}\text { Teacher promotes commitment of parent and } \\
\text { community to school. }\end{array}$ & 0.73 & 0.75 & 3.38 & 4.32 & $\overline{0}-94$ & $-\overline{19.28}$ & 352 & .000 \\
\hline Teacher tackles ethical dilemmas of students. & 0.58 & 0.57 & 3.40 & 4.22 & $\overline{-}-8$ & $-\overline{19}$ & 352 & .000 \\
\hline $\begin{array}{l}\text { Teacher involves in research to explore the new } \\
\text { knowledge }\end{array}$ & 0.72 & 0.63 & 3.29 & 4.28 & -1 & $-\overline{2}-95$ & 353 & .000 \\
\hline $\begin{array}{l}\text { Teacher manages their own professional } \\
\text { development }\end{array}$ & 0.72 & 0.95 & 3.13 & 3.94 & $\overline{-}-\overline{1}$ & -14.34 & 353 & .000 \\
\hline
\end{tabular}

Source: Field Survey, 2019

The study had checked the significant difference between the current level and expected level of teacher's role in quality education. The statistical test of paired sample t-test shows that there was significant difference between current level and expected level because the $\mathrm{p}$ value of all indicator is less than .01 significant level which indicates the need of improvement in role of teachers to improve the quality education.

The study had discussed with the different stakeholders of education like head teacher, teachers, students, parents, School Management Committee to know the current status of teaching and learning system and role of teachers to improve the quality of education. All the stakeholders realized the need of improvement in role of teachers. Head teacher is responsible to monitor the overall performance of school including preparation of reading materials by teachers, their punctuality in school time, teaching method, interaction with students, use of modern technology in class teaching, checking of assignment of students in time, feedback system, etc. Teacher's role is very important to determine the student learning, performance and academic achievement. As in discussion with parents, they were more dependent on the teaching of teachers for the betterment of their children. They thought that teachers would guide seriously to their children in school time whereas teachers were expecting the more guidance to students from parents in house. But in reality it was noticed that all parents were not equally able to guide in the course content to their children; just they ask their children to study at house. So, in such condition, teachers should be more responsible to see the progress of students even in the leisure and holiday time.

Head teacher and school management committee realized the lack of regular training, seminar and workshop to teachers to enhance their teaching capacity. All teachers should be trained on teaching and learning method should have advance skill of use of ICT (information, communication technology) in teaching, interpersonal communication skill and teachers should have motivational skill to motivate the students for study. During the field visit, many teachers showed their interest to participate in training program to update their knowledge. 


\section{Conclusion}

The study had discussed on the role of teachers to improve the quality education in secondary level public school. The result shows that the role and effort of teachers in current practice level was lower than the expected level of their role by the concerned stakeholders. So, it can be concluded that there is need of improvement in role of teachers to enhance the quality education. The school management committee, head teachers and other stakeholders should provide the opportunity to teachers to participate in advance level of training, workshop and seminar to get the new knowledge of teaching and learning.

\section{References}

Adhikary, D. M. ( 2018 , December). Role of Teachers in Quality Enhancement Education and Human Development. International Journal of Humanities and Social Science Invention (IJHSSI), 7(12), 34-41. Retrieved September 9, 2019, from http://www.ijhssi.org/papers/vol7(12)/Ver-2/C0712023441.pdf

Darling-Hammond, L. (2013). The importance of quality Education: From start to End .

Nagoba, B. S., \& Mantri, S. B. (2015, Jan-Mar ). Role of Teachers in Quality Enhancement in Higher Education. Journal of Krishna Institute of Medical Sciences University , 4(1), 117-182. $\quad$ Retrieved $\quad$ September $9, \quad 2019$, from https://www.researchgate.net/publication/282928863_Role_of_Teachers_in_Quality_Enh ancement_in_Higher_Education

Thangeda, A., Baratiseng, B., \& ThatoyamodimoMompati. (2016 ). Education for Sustainability: Quality Education Is A Necessity in Modern Day. How Far do the Educational Institutions Facilitate Quality Education? Journal of Education and Practice, 7(2), 9-17. Retrieved September 6, 2019, from https://files.eric.ed.gov/fulltext/EJ1089752.pdf

UNESCO. (2004). EFA Global Monitoring Report 2005: Education for All - The Quality Imperative. Paris: UNESCO.

Wayne, A., \& Youngs, P. (2003). Teacher characteristics and student achievement gains: A review. Review of Educational Research, 73(1), 89-122. 